\title{
Presentation and follow up of a newborn with glutaric aciduria type 1
}

\author{
*Mili Thomas ${ }^{1}$, Kamala Swarnam², Sindhu Sivanandan², Lekha Hrishikesan ${ }^{3}$ \\ Sri Lanka Journal of Child Health, 2020; 49(3): 292-294 \\ http://dx.doi.org/10.4038/sljch.v49i3.9152 \\ (Key words: Glutaric aciduria, metabolic acidosis, newborn screening, inborn errors of metabolism)
}

Glutaric aciduria type 1 (GA-1) is an autosomal recessive disease due to deficiency of glutaryl-CoA dehydrogenase $(\mathrm{GCDH})^{1}$. GCDH gene is located on chromosome $19 \mathrm{p} 13.2^{2,3}$. GA-I is characterized by accumulation of glutaric acid, 3-hydroxyglutaric acid, glutaconic acid and glutaryl carnitine which are detectable in body fluids and tissues by gas chromatography-mass spectrometry (GC-MS) or electrospray-ionization tandem mass spectrometry ${ }^{4,5}$.

\section{Case report}

An eleven day old baby girl, born of a third degree consanguineous marriage (first cousins) presented with poor feeding, decreased urine output and weight loss. Baby was born at term with a birth weight of $3.75 \mathrm{~kg}$ and was on breast feeds. At admission, baby's weight was $2.5 \mathrm{~kg}$, with more than $30 \%$ weight loss. She was irritable with poor perfusion and severe dehydration with wellpreserved reflexes. There was no organomegaly.

Investigations revealed very high serum sodium levels $(164 \mathrm{mEq} / \mathrm{L})$ and normal potassium and glucose levels. Blood gas showed high anion gap metabolic acidosis, with normal ammonia levels and no ketosis. Sepsis work up was negative and 17 hydroxy progesterone levels were normal. In view of the high anion gap metabolic acidosis and consanguinity, tandem mass spectrometry and urine organic acid profile by GC-MS were done and turned out to be positive for GA-1.

Genetic test showed a homozygous missense

${ }^{1}$ Junior Consultant, ${ }^{2}$ Senior Consultant,
Department of Pediatrics and Neonatology, ${ }^{3}$ Senior Consultant, Department of Pediatric Nephrology, Ananthapuri Hospitals and Research Institute, India

*Correspondence: militreesa@gmail.com

(iD) orcid.org/ 0000-0002-5356-2790

(Received on 04 February 2019: Accepted after revision on 22 March 2019)

The authors declare that there are no conflicts of interest

Personal funding was used for the project.

Open Access Article published under the Creative

Commons Attribution CC-BY (C) (P) variation in the exon 6 of glutaryl-CoA dehydrogenase (GCDH) gene (Chr 19:13004408; $\mathrm{T}>\mathrm{C}$ : Depth 99x) that results in amino acid substitution of threonine for methionine at codon 149 (p.Met149Thr). Magnetic resonance imaging (MRI) of brain at 3 months of life showed widened bilateral sylvian fissures, bilateral T2W hyperintensities in the globus pallidus and volume loss of bilateral temporal lobes (Figure 1)

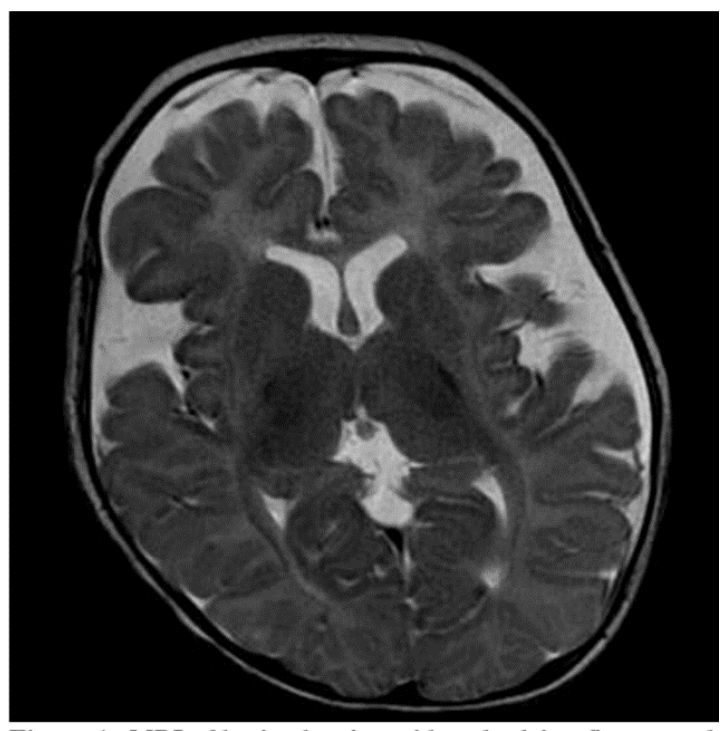

Figure 1: MRI of brain showing widened sylvian fissure and temporal lobe atrophy

Hypernatraemia and acidosis were corrected. Empirical intravenous antibiotics were given till cultures came back sterile. Baby was stabilized, lactation re-established and she started gaining weight.

Further management included medical nutrition therapy with low lysine diet along with breast feeds. Daily lysine intake was calculated and kept below the recommended level ${ }^{6}$. Predominantly lysine free formula (from Pristine Organics) along with breast feeds was given till 6 months. After 6 months, low lysine containing foods such as rice, sago pearls, banana, semolina, vegetables (like carrot, potato tomato) and fruits (like guava, apple, banana, papaya) were encouraged ${ }^{6,7}$. Ready to use low lysine containing rice based powder (Naturice) and low protein multipurpose flour were also used. Foods with high lysine content like egg, fish, meat, milk, pulses etc. were strictly avoided. Baby was supplemented with carnitine at $100 \mathrm{mg} / \mathrm{kg} /$ day and 
riboflavin at 200mg/ day. Written emergency management protocols were given to parents. Intercurrent infections were managed promptly to prevent recurrence of metabolic crisis. Later on, an older cousin of this baby, with dystonia was investigated and diagnosed to have GA-1 after this index case was identified.

Now baby is 2 years old with normal growth parameters. Due to strict adherence to the medical nutrition therapy and regular follow up by parents, there were no further episodes of metabolic crisis. Although we started low lysine diet early, she had already developed basal ganglia injury. She developed dystonia for which she was started on tetrabenazine. Her neurological symptoms are not progressing. She has motor development delay (DQ- 60\%) and other domains of development correspond with age.

\section{Discussion}

Infants affected with GA-1 can have normal development up to 2 years of age. However, macrocephaly frequently precedes onset of neurologic manifestations ${ }^{1}$. In contrast to other organic acidurias, GA-1 rarely presents in the neonatal period ${ }^{8}$. Untreated, approximately $90 \%$ of children with GA-1 will develop neurological disease associated with ketoacidosis, hyperammonaemia, hypoglycaemia and encephalopathy following gastroenteritis, intercurrent infection, immunisation or surgical intervention. Dystonia is the predominant extrapyramidal symptom, frequently superimposed on axial hypotonia ${ }^{9,10}$. Treatment includes:

1. Medical nutrition therapy-lysine free low tryptophan diet

2. L-carnitine $100 \mathrm{mg} / \mathrm{kg} /$ day

3. Riboflavin $200-300 \mathrm{mg} /$ day

4. Intensified emergency therapy during episodes of intercurrent illness.

Emergency therapy should begin promptly and aggressively during febrile illness, surgery and immunization. Natural protein is stopped for 24-48 hours and oral maltodextran solution or IV glucose is given according to the general condition of patient. This has markedly reduced the frequency of acute encephalopathy in patients who are diagnosed early ${ }^{6}$.

\section{References}

1. Rezvani, I. Lysine. In: Kliegman R, Stanton B, St.Geme III J, Schor N, Behrman R, editors. Nelson Textbook of Pediatrics, $20^{\text {th }}$ ed. Philadelphia: Elsevier; 2016. p. 676.
2. Fu Z, Wang M, Paschke R, Rao S, Frerman FE, Kim JJP. Crystal structures of human glutaryl-CoA dehydrogenase with and without an alternate substrate: structural bases of dehydrogenation and decarboxylation reactions. Biochemistry 2004; 43:9674-84.

https://doi.org/10.1021/bi049290c

PMid: 15274622

3. Greenberg CR, Reimer D, Singal R et al. A G-to- $T$ transversion at the +5 position of intron 1 in the glutaryl-CoA dehydrogenase gene is associated with the Island Lake variant of glutaric acidemia type I. Human Molecular Genetics 1995; 4:493-5 https://doi.org/10.1093/hmg/4.3.493 PMid: 7795610

4. Chace DH, Kalas TA, Naylor EW. Use of tandem mass spectrometry for multianalyte screening of dried blood specimens from newborns. Clinical Chemistry 2003; 40:1797-817.

https://doi.org/10.1373/clinchem.2003.022 178

5. Baric I, Wagner L, Feyh P, Liesert M, Buckel W, Hoffmann GF. Sensitivity of free and total glutaric and 3hydroxyglutaric acid measurement by stable isotope dilution assays for the diagnosis of glutaric aciduria type I. Journal of Inherited Metabolic Disease 1997; 22:867-82.

https://doi.org/10.1023/A:1005683222187

6. Kölker S, Christensen E, Leonard JV, Greenberg CR, Boneh A, Burlina AB, et al. Diagnosis and management of glutaric aciduria type I-revised recommendations. Journal of Inherited Metabolic Disease 2011; 34(3):677. https://doi.org/10.1007/s10545-011-92895

PMid: 21431622 PMCid: PMC3109243

7. Nutritiondata.self.com. (2003). SELF Nutrition Data | Food Facts, Information \& Calorie Calculator. [online] Available at: https://nutritiondata.self.com [Accessed 12 Oct. 2018].

8. Lindner M, Kölker S, Schulze A, Christensen E, Greenberg CR, Hoffmann GF. Neonatal screening for glutaryl-CoA dehydrogenase deficiency. Journal of Inherited Metabolic Disease 2003; 27:851-9. 
https://doi.org/10.1023/B:BOLI.00000457 69.96657.af

PMid: 15505392

9. Hoffmann GF, Trefz FK, Barth PG, Böhles HJ, Biggemann B, Bremer HJ, et al. Glutaryl-coenzyme A dehydrogenase deficiency: a distinct encephalopathy. Pediatrics 1991; 88(6):1194-203.

PMid: 1956737
10. Kölker S, Garbade SF, Greenberg CR, Leonard JV, Saudubray JM, Ribes A, et al. Natural history, outcome, and treatment efficacy in children and adults with glutaryl-CoA dehydrogenase deficiency. Pediatric Research 2006; 59(6):840. https://doi.org/10.1203/01.pdr.000021938 7.79887.86

PMid: 16641220 